\title{
The Intermarium As a Pivotal Geopolitical Buzzword1
}

\author{
Ostap Kushnir
}

Lazarski University

\begin{abstract}
This article focuses on historical and contemporary connotations of the Intermarium concept-Ukrainian and Polish academic and political thought on how to organize and govern the space between the Baltic and Black seas-employing the ideas of Józef Piłsudski, Józef Beck, Michał Czajkowski (Mykhailo Chaikovs'kyi), Mykhailo Drahomanov, members of the Brotherhood of Saints Cyril and Methodius, and other intellectuals. In this context, it traces Ukraine's and Poland's attempts to construct Intermarium-type intergovernmental frameworks in the aftermath of the Cold War. It also examines the current stage of Ukrainian-Polish co-operation-the latter being regarded by Intermarium founding fathers as a vital precondition for this framework to be realized. In this respect, the article considers bilateral advancements in political, economic, cultural, and security spheres. As the emergence of a Ukrainian-Polish institutionalized linchpin is impossible in the contemporary geopolitical architecture, the article proposes that the term "Intermarium" has become ambiguous. If by chance the Intermarium comes into being as a defensive alliance today, it might bring more harm than benefit to the regional security.
\end{abstract}

Keywords: Intermarium, Baltic-Black Sea area, Ukraine, Poland, foreign policy.

\section{INTRODUCTION}

$\mathrm{T}_{\mathrm{h}}$ he term "Intermarium" regularly appears in contemporary regional academic and political discourses. For instance, it is used by Polish officials, including the Polish president, Andrzej Duda, as a synonym for the Three Seas Initiative-an economic framework embracing states in an area connecting the Black, Baltic, and Adriatic seas (Sosnowski). The Intermarium lies at the heart of numerous academic events in Poland and

\footnotetext{
${ }^{1}$ I am grateful to Prof. Volodymyr Kravchenko, CIUS, who encouraged me to write an article on the Intermarium, and to the CIUS staff who provided a comfortable environment to finalize the article during my stay as the Kolasky Research Fellow. Anonymous reviewers have been prolific with comments and recommendations that were relevant to the topic, and the article would not have been as well-rounded without the works and elaborations of my friends and colleagues in academia.
} 
Ukraine, bringing together specialists on regional affairs (for example, 2017 conferences in Warsaw and Chernivtsi, the 2018 Round Table in Kharkiv, the 2019 Conference in Ostrowiec Świętokrzyski, and the 2020 online Round Table initiated by the Kyiv's Institute of Democratization and Development). The programs of political parties and organisations, such as the so called far-right paramilitary organization Azov in Ukraine, present the Intermarium as an alternative to the European Union (EU) (Wishart). Finally, journalists, policy analysts, politicians, and social media contributors often refer to the Intermarium to justify political objectives and strategies (for example, Iurii Honcharenko, Kostiantyn Fedorenko, Andreas Umland, Iryna Vereshchuk, and Sviatoslav Iurash ${ }^{2}$ ). In this light, the article explores the historical and contemporary connotations of the Intermarium to assess the general relevance of the term to the geopolitical realities of the early twenty-first century.

Contemporary Ukrainian-Polish co-operation is a key precondition for the emergence of an Intermarium intergovernmental framework, at least in its original characterization. Without a collaboration between these two major central and eastern European powers, it is unlikely that the other regional actors, specifically Baltic and Black Sea states, will consider joining the regional centripetal framework broadly defined as the Intermarium. However, it remains unclear whether a Ukrainian-Polish linchpin will emerge soon, if ever.

What should be understood about the Intermarium concept today? What are its historical and geopolitical meanings? To what extent does the original Intermarium concept constitute an attractive model of cooperation? Could a Ukrainian-Polish linchpin secure the functioning and flourishing of an Intermarium framework? To answer these and other questions, the article will draw from the collected volume Intermarium: The Polish-Ukrainian Linchpin of the Baltic-Black Sea Cooperation (Kushnir).

The article puts forward a hypothesis that the Intermarium concept should be removed as a realistic framework of co-operation from public and political discourses. The ambiguity of its connotations and the diversity of its interpretations make this concept poorly suited to outline and propel contemporary interstate relations in the central and eastern European region. In the aftermath of the Cold War, the Intermarium became an allembracing buzzword, which was emotionally inspiring but futile for practical policy-making. The evidence cited here suggests that contemporary regional co-operation should be erected on premises that exclude the Intermarium concept.

2 In October 2020, Sviatoslav Iurash initiated the creation of the inter-factual union "Intermarium" in the Parliament of Ukraine. 
POLISH AND UKRAINIAN CONCEPTS OF THE INTERMARIUM: HISTORICAL OUTLINE

The "Intermarium" as a term and geopolitical concept first emerged in Polish political thought. Józef Piłsudski, the Polish Chief of State and Supreme Commander, brought it to life in the turbulent environment of central and eastern Europe at the beginning of the twentieth century (Masson; Nałecz, "Intermarium vs the Three Seas Initiative").

An earlier Piłsudski masterplan in the 1890s, which had not yet been defined as an Intermarium, envisioned a reinforcement of the nationalist aspirations of local peoples to change the geopolitical architecture in the region. This masterplan emerged almost twenty years before the American president, Woodrow Wilson, delivered his declaration on the right to selfdetermination of European nations. A major Piłsudski objective was for Poland, having regained its independence, to provide a security backbone for a new balance of powers. That was a hard objective to achieve. Piłsudski and other members of the Socialist party had no doubts that Poland would not survive long in the geopolitical atmosphere of the Russian Empire. They argued that the empire should be partitioned along its ethnic and national divisions. To accomplish that partitioning, they planned to initiate a widescale revolt in the region that would result in a federation of newly-born regional states led by Poland (Nałęcz, "Intermarium vs the Three Seas Initiative"; Dahl 62). This early masterplan outlined all the elements that Piłsudski would refer to in building his Intermarium strategy in the late 1910s:

The most important of those elements resided in considering Russia as the biggest threat to the freedom of the nations of Eastern Europe, unification of those nations in the fight against Russian expansion, the key role of Poland in this fight, and the transformation of Poland into a regional leader. (Nałęcz, "The Evolution" 2-3)

According to Nalęcz, the Intermarium in contemporary Polish political thought fluctuates between three distinct, yet not always distinguishable, conceptual dimensions. The first refers to Piłsudski's ambition to create a federation of newly independent states following the collapse of the Russian Empire in 1917. The second dimension presents the Intermarium as a broadly understood framework of a multi-layered beneficial cooperation between all the actors in central and eastern Europe. This framework cannot be precisely defined, as its nature depends on colliding theoretical perspectives and speculations. It also cannot be clearly connected to Piłsudski's masterplan. The third dimension presents the Intermarium as a purely geographical region stretched between the Baltic and Black seas, or between the Baltic, Black, and Adriatic seas. This dimension is often used to "justify" the portrayal of the Three Seas Initiative 
as the Intermarium project, and has much to do with the 1930s' speculations of the Minister of Foreign Affairs, Józef Beck (Nałęcz, "Intermarium vs the Three Seas Initiative"). ${ }^{3}$

A major weakness of the second conceptual dimension is that Piłsudski never clearly defined which states should be invited into the federative block and which should not. The regional environment of the late 1910s was volatile and changeable; thus, it was hard for Piłsudski to predict which nations would secure their statehood after the collapse of the Russian Empire. This historical ambiguity never completely disappeared from the Polish political theorizing. It continues to generate different, and often colliding, ideas behind the Intermarium concept, all placed under a common denominator (Nałęcz, "The Evolution" 3-4).

Although ideas of how to govern the space between the Black and Baltic seas regularly reappeared in Ukrainian political thought, Ukrainian and Polish conceptualizations of the Intermarium favour different geopolitical patterns. Above all, the term "Intermarium" came from beyond the western border of Ukraine and lacks clear indigenous roots in Ukrainian historiography. According to Poltorak, Ukrainian intellectuals and politicians of the early twentieth century constructed frameworks for regional governance based on Kyivan Rus' and Cossack semi-statehood traditions. These frameworks were usually defined as "Baltic-Black Sea axis" or "Baltic-Black Sea area," not "Intermarium." They were often more south-oriented than the Intermarium and embraced the Caucasus states, Romania, Bulgaria, and Turkey. Last but not least, Ukrainian conceptualizations of the regional governance occasionally portrayed Poland as an alien or competitive element; in particular, that was the vision of Stepan Rudnyts'kyi (Poltorak 34). Alternatively, Polish historical conceptualizations of the Intermarium demonstrated a clear inclination toward a reconstruction of the Polish-Lithuanian Commonwealth with its reinforced north-eastern stance (Chodakiewicz 5-6). Recognizing the geopolitical importance of the southern states, Polish theorists drew from Piłsudski's masterplan and often prioritized interdependencies of the Baltic states, Belarus, and Ukraine.

The "golden age" of Ukrainian political theorizing of regional governance lasted from the mid-nineteenth to the early twentieth centuries.

\footnotetext{
${ }^{3}$ In the late 1930s, the Polish Minister of Foreign Affairs, Józef Beck, expanded the initial Intermarium concept to embrace Hungary, Italy, Yugoslavia, and Romania. Beck is considered to stand behind a plan to connect the Gdynia port on the Baltic Sea to Sulina on the Black Sea, through river passages and railways. Transport infrastructure was supposed to boost the GDP, as well as the overall development of all regional states.
} 
Concepts of a loose federation were the most popular in that period. Ukrainian concepts differed from Polish concepts, however, as the former envisaged either the democratization and re-formatting of the Russian Empire, or the creation of a brand-new Slavic federation with Ukraine at its core. The most prominent proponents of a loose federalization were the members of the Brotherhood of Saints Cyril and Methodius (above all, Heorhii Andruz'kyi and Panteleimon Kulish), as well as Michał Czajkowski (Mykhailo Chaikovs'kyi) and Mykhailo Drahomanov (Poltorak 31-33; Kushnir, Ukraine and Russian 54). In the majority of federative concepts, Ukraine was expected to gain weight in regional governance and project its power into the Middle East, and even into North Africa (Kushnir, "Ukrainian Policies" 165-66). This kind of theorizing collided with Piłsudski's masterplan geopolitically, not to mention that Poland was moved to the backstage. Moreover, alongside Piłsudski's attempts to construct his Intermarium in the aftermath of World War I, Ukrainian statesmen did their best to develop the Baltic-Black Sea axis. This can be seen in the deliberate efforts of Pavlo Skoropads'kyi and Symon Petliura to build strong relations with axis states, from Finland to Turkey. Later, these efforts were continued by nationalist theorists and leaders in the 1930s-40s (Poltorak 39-40).

As historiography and history of political thought reveal, differences between Ukrainian and Polish Intermariums are unyielding. While generally favouring the federative concept of co-operation in the BalticBlack sea space, Ukrainian and Polish concepts from the early twentieth century placed different actors at the core of such co-operation and preferred colliding geopolitical orientations (north-east vs. south). The key terms they used were also different, and these differences made a significant impact on contemporary perceptions of the Intermarium.

Post-Cold War Relations on the InTERmarium Playground: UKRAine AND POLAND

The inbred multi-layeredness of the Intermarium concept nurtured its diverse interpretations by different theorists and decision makers. One may even state that the Intermarium evolved into an all-embracing term in contemporary public and political discourses, a term equally suitable to define any international organization or framework of co-operation in central and eastern Europe. As anticipated by Piłsudski, none of the existing regional organizations or frameworks could boast of a sufficient degree of coherence. There are numerous illustrations of this lack of coherence.

To begin with, at its very dawn, the Visegrád Group (Czechoslovakia, Hungary, and Poland) was portrayed by some analysts and journalists as an Intermarium-type of state alliance. In 1993, after the partition of 
Czechoslovakia, the group acquired its final shape and declared its major objectives. These involved mutual support and collaboration on the issues of NATO membership, EU integration, foreign policy coordination, and deepening internal co-operation. The Visegrád Group included the most regional states and secured the highest diplomatic level of dialogue since the inception of the original Intermarium concept (Chojan 87; Jabłoński 34).

However, the Visegrád Group never developed a shared identity or a feeling of interdependence. The spirit of "Visegrád-ness," as put forward by Borkowski, which was supposed to nurture the spatial traits of the Intermarium region, did not come into being (38). The Group also failed to form a unified stance with respect to international actors, for instance, Russia. In this light, Fiszer claims that the idea of consolidating central Europe in opposition to Russian influences, as argued by Piłsudski, was utopian for the Visegrád Group (58). Regardless of declarations, there always existed discords in national interests:

Hungary has excellent relations with Russia, and this means that Poland de facto does not have an essential strong regional partner by its side .... The Czechs and Slovaks would prefer to come to an understanding with Russia and do not intend to put a spoke in its wheel. Thus the idea of building a new Central Europe (the "Intermarium"), where Warsaw would play first fiddle and the bloc of Visegrád Group countries would be a barrier against Russian influences in Europe, does not seem realistic. (Fiszer 58)

Moreover, to manifest the fragmentation of the region even more, Ukraine was not invited to join the Visegrád "Intermarium" Group. Attempts by the Ukrainian president, Leonid Kravchuk, to apply diplomatic pressure in the early 1990s did not bear fruit. Poland and some of the other Visegrád states were on a road that led to European and Trans-Atlantic alliances, and Ukraine was perceived to be an unnecessary burden. Actually, the only pro-Intermarium power in the Visegrád Group in the 1990s was the Polish right-wing political party Confederation of Independent Poland (Konfederacja Polski Niepodległej). Scoring 5.77\% in the 1993 parliamentary elections, though, the party lost influence on Polish foreign policy (Kushnir, "Ukraine, Poland" 54-55). Poland abandoned the idea of making up a formalized linchpin with Ukraine.

Having learned from Kravchuk's failures, in the late 1990s the Ukrainian president, Leonid Kuchma, attempted to revive the geopolitical potential of the Baltic-Black Sea axis without Poland. That was in line with what Ukrainian theorists of the early twentieth century argued about when they occasionally portrayed Poland as an alien or competitive element. On 28 December, 1998, Kuchma issued an order to prepare an international conference: "Baltic-Black Sea Cooperation: Towards an Integrated Europe 
of the XXI Century Without Separating Lines." The conference took place in Yalta on 10-11 September 1999, and concluded with Kuchma's call to create an intergovernmental organization uniting the regional states on the north to south axis. This was wishful thinking. The geopolitical incompatibilities of the eastern European region would prevent any kind of coherent integration. President Aliaksandr Lukashenka of Belarus was not present at the conference, and this removed Belarus from the initiative. Representatives of the Baltic states were sympathetic, but restrained; they invariably favoured NATO, the EU, and northern European projects. Russia was straightforwardly hostile and sabotaged any kind of integration, an attitude that excluded its membership in the proposed intergovernmental organization. All these conflicts of interests and objectives led to no breakthrough in the regional geopolitical architecture (Bykanov 56; Shpak 173).

At least two organizations-Organization for Democracy and Economic Development-GUAM (ODED-GUAM, where GUAM stands for Georgia, Ukraine, Azerbaijan, Moldova) and Organization of the Black Sea Economic Cooperation (BSEC) - today stand closest to Ukraine's indigenous visions of governance in the Intermarium region. Both are south-oriented, embrace Caucasus states, and aim to project their influence into the Middle East. Both organizations share the following similar characteristics: (i) economic co-operation is strongly favoured over political unification (they occasionally attempt to resolve political issues by economic means, for example, the Nagorno-Karabakh conflict between Armenia and Azerbaijan); (ii) efficiency is modest, as their member-states mistrust one another and tend to underperform or misinterpret multilateral decisions; (iii) similar objectives that happen to be in collision are promoted, such as free trade zones or transport corridors.

The BSEC was not initiated by Ukraine, but by Turkey in 1992, and is exploited by Russia to lobby Russian objectives and reinforce the Russian regional stance. Ukraine is the dominant player in ODED-GUAM; however, Ukraine is unable to contain Russian presence in the Black Sea and its littoral regions. ODED-GUAM is comparatively "weak," as it is comprised of only four states, none of which is a clear regional power. Other states on the Baltic-Black Sea axis either perceive the ODED-GUAM as a competitor (Turkey) or are content to remain observers (Latvia). Therefore, Ukraine's visions of Intermarium governance cannot be efficiently implemented in the contemporary geopolitical architecture, and little is expected to change in the near future (Kushnir, "Ukraine, Poland" 55-64).

Contemporary Ukrainian-Polish bilateral co-operation, far from being good-neighbourly and productive, is subject to diplomatic breakthroughs and downturns. According to Pryshchepa, Poland engages in relations with Ukraine only when Ukraine's domestic and foreign policies meet Polish 
expectations. Poland expects Ukraine's efforts to become more democratic to follow a path similar to that of Poland. If Ukraine underperforms or plunges into political crisis, Poland demonstrates fatigue and alienation. For example, from 1999 to 2007, Ukrainian-Polish relations suffered notable blows with the assassination of Georgiy Gongadze, a Ukrainian journalist of Georgian origin, and the Ukrainian disregard of international sanctions when it sold Kolchuga radar systems to Iraq. Following the Orange revolution of 2004 that erupted in the aftermath of a Ukrainian presidential election, claimed to be marred by massive corruption, voter intimidation, and electoral fraud, the Polish president, Aleksander Kwaśniewski, served as a moderator between conflicting sides during round table talks. Polish optimism regarding Ukraine started to grow, but not for long. PolishUkrainian relations cooled again after the Warsaw authorities learned that the incoming government had failed to introduce much needed domestic reforms (Kowal and Ukielski; Pryshchepa 92-93).

Poland recognizes that EU institutions have an upper hand in shaping foreign policy. This prevents Poland from taking strategic unilateral actions regarding Ukraine. Poland improvises in its contemporary relations with Ukraine, but it plays for the EU team. Occasionally Poland recognizes that West-supported policies will not meet Ukraine's interests. If this happens, unable to change the course of events, Poland steps aside in the long run. As Ukrainian-Polish co-operation invariably depends on the domestic and international circumstances in each country, it does not constitute a firm strategic objective today (Pryshchepa 100-01; Jaroszewicz and Grzymski 269-70).

Another important issue preventing the Ukrainian-Polish linchpin from coming into being is a colliding interpretation of a shared history. Poles seek a just and fair recognition of the crimes committed by Ukrainians in the mid-twentieth century, whereas Ukrainians "forgive" Poles for their "records of oppression" and wish to build friendly relations from scratch (Osadczuk 143). However, the political agenda in Poland is significantly influenced by right-wing sentiments today, while Ukraine is re-assessing its history and re-inventing its identity (Jaroszewicz and Grzymski 270). Moreover, neither state agrees to grant access to all of the available data on the Volhynia crimes of 1940s, or ambiguous activities of the Ukrainian Insurgent Army (UPA) and Polish anti-Nazi resistance. The occasional statements of reconciliation made by public figures in both states are more about diplomacy than attempts to resolve the tensions.

According to Pryshchepa, the potential of a Ukrainian-Polish linchpin resides in implementing "calculable" and pragmatic policies for trade, labour migration, energy supplies, and security co-operation that demonstrate a healthy growth from year to year. If successful, these policies 
could overshadow the highly provocative and manipulative historical bilateral debates (Pryshchepa 103).

ThE INTERMARIUM FOR SECURITY AND ECONOMIC SUSTAINABILITY: Wishful THINKING

Although the security of Poland and its allied states constituted a key objective of Piłsudski's Intermarium concept, it has no chance of being implemented today. Bugriy speculates that a military alliance between Ukraine and Poland could potentially destabilize the whole region. Instead, the two states are in a process of constructing a flexible and adjustable strategic alignment against a common threat, Russian neo-imperialism (Bugriy 114). This strategic alignment takes on different guises.

Poland undertakes a number of activities to export its transformational experience to Ukraine. Polish officials and military staff pay numerous visits to their colleagues in the east, while Polish security experts join a variety of coordinating and advisory bodies (e.g., the Comprehensive Assistance Package within the NATO-Ukraine platform). Moreover, Poland serves as an advocate and lobbyist of Ukrainian interests in western intergovernmental structures. Because of this, Ukraine acquires many more opportunities to co-operate with NATO, such as participation in peacekeeping missions or joining Trans-Atlantic drills.

However-and this constitutes a major digression from the Piłsudski's Intermarium concept-Poland prefers to build its defence and security cooperation with Ukraine within the frameworks of European and TransAtlantic alliances, in particular, NATO, the EU, and the UN, organizations that exceed the Intermarium region and include states that Piłsudski regarded as imperial bullies at the beginning of the twentieth century. Ukraine strives to upgrade its institutions and material base to achieve the level of staff proficiency required to join these structures (KlympushTsinsadze). No influential political actors in Ukraine and Poland regard the Intermarium as an alternative to European and Trans-Atlantic integration. Joint Ukrainian-Polish military units have some symbolic and political value but little military power. The most renowned of these units-the LITPOLUKRBRIG, with a staff of 4,500-is miniscule compared to the Polish and Ukrainian armed forces, and is unlikely to engage in wartime military operations. The major contribution of the LITPOLUKRBRIG resides in providing highly intensive and sophisticated training to military staff of both states (Ryabykh; Domaradzki 270).

One of the most promising areas of Ukrainian-Polish bilateral cooperation is the joint development of sophisticated weaponry. A number of companies from both states (e.g., Ukroboronprom, WB Electronics S.A., 
Huta Stalowa Wola S.A., Chernihiv's Plant of Radio Equipment, Bumar Łabędy S.A.) have indicated interest in working on unmanned battle drones and armoured vehicles, anti-aircraft and anti-missile equipment, mortar and artillery systems, multiple rocket launchers, and in upgrading existing equipment and machinery to NATO standards. However, regardless of its inspiring dynamics, the level of ongoing technological co-operation remains modest (Ryabykh; Bugriy 126-28; Ministry of Foreign Affairs, Republic of Poland).

Despite ongoing bilateral security co-operation, the Ukrainian-Polish defence-oriented linchpin is not obviously under construction today. The term "Intermarium" is likely a misnomer regarding the regional security architecture. Contemporary Ukrainian-Polish security co-operation has neither the geopolitical impact, nor the institutional interdependence to realize Piłsudski's concept of an Intermarium. In addition to these incongruities, its framework has evolved to exceed the Intermarium geographical area and is connected to European and Transatlantic structures. The term Intermarium is also misleading when defining Ukrainian-Polish co-operation on the eastern NATO flank (see Gniazdowski). The cornerstones on which the Intermarium and NATO are built are incompatible, as the Intermarium prioritizes regional independence and self-sustainability whereas NATO encourages global reach and membership. What is being build today between Poland and Ukraine is not a classical military alliance, it is an alignment that provides no firm security guarantees and commitments. At the same time, this alignment avoids irritating global players, such as Russia and China, who tolerate non-formalized security developments between smaller states in the region.

The level of economic co-operation within the Intermarium region is modest. According to Napiórkowski, the biggest central European market for Ukrainian goods is Poland. It is therefore in the interest of Kyiv to increase the quality and volume of trade with its western neighbours. This said, the Polish market and other markets in the Intermarium states account for a very small portion of Ukraine's exports. Paradoxically, in spite of Russia's annexation of Crimea and its confirmed participation in the military conflict in Donbas, the volume of Ukraine's trade with Russia in 2017 exceeded the volume of trade with Intermarium states (i.e., in January-December 2017, 9.62\% of Ukraine's exports went to Poland, Belarus, Latvia, and Lithuania, whereas $32.88 \%$ went to Russia) (Napiórkowski 153-54; State Statistics Service of Ukraine). This trend continues in 2020.

Although an increase in Ukraine's trade with the Intermarium states should remain an indisputable priority, a wider framework would be more profitable. Supporting Pryshchepa's arguments, Napiórkowski 
unequivocally concludes that Ukraine should prioritize trade with the EU over regional trade, as the EU can provide many more short-term and longterm benefits. Ukraine should also consider attracting low-technology foreign direct investment (FDI) from more developed states, notwithstanding their geopolitical affiliations, and build absorptive capacity in Ukraine so that high-technology FDI may be eventually accommodated (Napiórkowski 159-60). This economic strategy has worked well for other states in the Intermarium region, which, unlike Ukraine, are now EU member-states.

\section{INTERMARIUM ALTERNATIVES FOR THE TWENTY-FIRST CENTURY}

EU states and states in the European economic area (EEA) (for example, the twelve states in the Three Seas Initiative and the Nordic-Baltic Eight), which are thought to belong to a wider Intermarium region, actively developed authentic intergovernmental frameworks at the beginning of the twentyfirst century. Some of these intergovernmental frameworks were coinitiated by Poland and portrayed in public discourse as Intermariums. Similar to the formation of the Visegrád Group in the 1990s, Ukraine was not invited.

The Three Seas Initiative gained momentum after the 2015 victory of the conservative Law and Justice (Prawo i Sprawiedliwośc) Party in Poland. The party leadership and the newly elected president, Duda, sympathized with Piłsudski's traditions of regionalization and unequivocally stated that Polish foreign policy should be reconsidered to benefit the new geopolitical environment. Such reconsideration entailed a reinforcement of the existing organizations-for example, the Visegrád Group-and a fostering of regional co-operation within the EU, plans that yielded the Three Seas Initiative (Dahl 59; Fedorenko and Umland).

As mentioned in the Dubrovnik Declaration of 26 August 2016, the Three Seas Initiative did not envision the creation of governing structures parallel to those of the EU. The Three Seas Initiative was designed as an informal platform that could gain political support and could implement decisive actions in specific cross-border and macro-regional projects. An emphasis was placed on coordination and co-operation in strategic sectors of energy, transport, digital communication, and economy in central and eastern Europe (Official Website of the President of the Republic of Poland). As Krzysztof Szczerski, head of the Office of President Duda, emphasized,

the Three Seas Initiative is primarily an initiative for regional co-operation within the European Union, within the EU member-states, together with the EU, using the EU, its funds, development projects so that regional co- 
operation could be strengthened, so that the countries of our region could be better connected with each other, so that our region could be better connected with all other European countries. ("Szczerski"; see also Dahl $65)^{4}$

However, co-operation within the Three Seas framework predominantly focuses on enhanced distribution of EU cohesion funds, not on the strengthening of regional identity and integrity. This co-operation lacks solid administrative structure and does not profoundly address security and defence issues. Some of the regional states are lately anxious about the growing Polish neo-imperialism, and therefore favour direct cooperation with the EU and Transatlantic structures. Some of the states are also concerned about Polish anti-European, anti-German, and anti-Russian stances that could develop into threats in the future. As in the Piłsudki era, the Three Seas region is too fragmented to speak in one voice. The issue of inviting Ukraine into the Three Seas Initiative rarely appears on the agenda. Poland does not lobby Ukraine's inclusion, thus keeping one of Piłsudski's geopolitical linchpins dismantled.

The geopolitical situation looks comparatively similar to the north from Kyiv and Warsaw. The Nordic-Baltic Eight (NB8) is an informal framework for regional co-operation that provides political leaders from five Nordic and three Baltic States an opportunity to discuss issues of regional and international importance (Ministry of Foreign Affairs, Republic of Estonia). Ministers from Finland, Sweden, Norway, Iceland, Denmark, Estonia, Latvia, and Lithuania meet regularly to establish development objectives for their states and to coordinate national policies. These meetings take place outside the institutional structures to allow participants to express their thoughts openly and flexibly. However, the informality also means that NB8 decisions rarely evolve into binding commitments (Iso-Markku et al. 9).

The NB8 is a scattered framework. There exists no shared identity or shared political culture in northern Europe. The NB8 framework is full of smaller divisions, subgroups of the Nordic and Baltic states. The small divisions include EU members who have created separate forums to discuss internal issues. The Nordic states each have a separate program of cooperation in military and defence spheres (Archer and Joenniemi 173). In contrast to the interwar Intermarium spirit, the Nordic-Baltic states continue to prioritize narrow common national interests rather than panregional concerns.

However, the NB8, unlike the Three Seas Initiative and the Visegrád Group, has a comparatively well-established foreign and security policy dimension. At certain points, it exceeds EU framework and works as a non-

${ }^{4}$ Unless otherwise noted, all translations in this study are mine. 
aligned "cluster" or "island" (Archer and Joenniemi 166). The 2018 Nordic Defence Cooperation Report states that NB8 regional security gained importance in the light of the "gradual weakening of multilateral institutions, the consequences of the economic and financial crisis in Europe, the expected US 'rebalance' towards Asia (and away from Europe), as well as the growing strategic importance of both the Arctic and the Nordic-Baltic region" (Iso-Markku et al. 5). However, the most efficient security and foreign policy tools possessed by the NB8 are co-managed by larger players and frameworks. One such tool is the Enhanced Partnership in Northern Europe (e-PINE), launched by the United States. In a nutshell, these are regular NB8+USA meetings with objectives to increase freedom, security, and prosperity in the region and its neighbourhood. The neighbourhood includes post-Soviet and post-communist states (in particular, Ukraine), as well as the Visegrád Group members. In achieving their objectives, the NB8 states significantly rely on the mechanisms in EU Eastern Partnership programs.

In sum, the NB8 is a new framework with flexible and dynamic regional co-operation but limited institutional efficiency. It does not anticipate that states from the broader Intermarium region will ever become its members. Although the NB8 allows for a variety of formalized structures and informal incentives to be balanced, it does not fit the original Intermarium concept.

\section{Is THERE A CHANCE TO MAKE THE ORIGINAL INTERMARIUM CONCEPT WORK?}

Today, some of the major advocates of the Intermarium concept are Andreas Umland, Kostiantyn Fedorenko, and Iryna Vereshchuk. They claim that the post-Cold War era brought significant political divisions, and therefore fragility to the geopolitical architecture, into the Baltic-Black Sea region. Some of the regional states successfully joined the broader Western frameworks, while some remained in the so-called "grey zone," torn between the interests of NATO, the EU, and Russia. The Intermarium concept of genuine co-operation was proposed as a way to address the "grey zone" security challenges and introduce long-term stability to the Baltic-to-Black Sea axis. In turn, this stability should reinforce the stance of regional actors against Russia without the necessity of NATO and EU enlargements.

Fedorenko and Umland claim that the regional fragility is twofold. On the one hand, the Western actors failed to send clear signals to half of the post-communist states that the latter would be accepted in the European community. For instance, the 2008 NATO Bucharest Declaration did not include any Membership Action Plans for Ukraine and Georgia, and the much debated EU Eastern Partnership did not envision any security 
guarantees. The EU policy toward the eastern neighbourhood is built upon comprehensive association agreements, not on membership prospects (Domaradzki 282; Grzymski 141). On the other hand, the Western actors failed to incorporate Russian interests into a regional security architecture. In the early 1990s, the co-operation between Russia and NATO looked very promising; the Russian Minister of Foreign Affairs even referred to the NATO nations as "natural friends and ... future ... allies" (Forsberg and Herd 44). The EU members, in turn, breathed a sigh of relief when Russia allegedly transformed into a "normal" state. However, western Europe and the Kremlin have different perceptions of "normality." European actors perceived the promotion of democracy, the creation of free markets, and the establishment of human rights to life, liberty, and security to be natural goals, whereas their Russian counterparts had doubts about such objectives (Tsygankov 289-90). Eventually, President Vladimir Putin condemned the West for regularly cheating Russia and declared that his state would pursue its foreign objectives regardless of Western opinion. To make matters worse, contemporary Western public opinion does not regard the states east of Poland as truly Western and properly European. Iron Curtain divisions continue to thrive in contemporary discourses. Lacking an eloquent public request, the leaders of NATO and EU states are not keen to invite "grey zone" states into their frameworks, even in the long run.

Fedorenko and Umland argue that under the pressure of Russian revisionism, the post-communist states will likely drift toward one another and amalgamate into a new framework, called the East-Central EuropeanSouth Caucasian defence coalition, with the states, constituting today's ODED-GUAM, as its core. After such framework is formed, the remaining states from the Intermarium region will likely support, join, or associate with it. To provide a rigid backbone to that framework, the regional NATO member-states may sign bilateral agreements to form strategic partnerships with their neighbours. Such a precedent was set in 2010 when Turkey and Azerbaijan signed the respective agreement. Article 2 of this agreement precisely outlines Turkey's obligations in case of a third power aggression against Azerbaijan. The same set of obligations may be introduced for the Intermarium region. Vereshchuk and Umland hypothesize that the US may favour such option and establish strategic partnerships with regional states (39-41).

However, as Burgriy demonstrated above, Fedorenko and Umland's concept of a hard-core defensive coalition with a developed military component is infeasible today (114). Agreements like the one Turkey signed with Azerbaijan will not likely be signed by regional NATO memberstates with their neighbours. In fact, there was an attempt to do something similar in 1992: the "NATO-bis" initiative (an international military agreement) raised by Polish president Lech Walęsa was criticized even by 
his closest advisers. Jacek Saryusz-Wolski, Poland's first Minister for European Integration, proclaimed the NATO-bis initiative to be "ill-fated" and "dangerous." Saryusz-Wolski postulated that any efforts to build military and defensive Intermarium-type frameworks will further undermine regional security, with Poland and Ukraine taking the major blows.

Building the Intermarium around the ODED-GUAM core is a counterproductive approach. One of the key ODED-GUAM objectives from 1997 was to resolve regional security issues without Russian engagement. That objective was not met; the 2008 war in Georgia and the 2014 crisis in Ukraine served as unquestionable examples. Overall, the efficiency of ODED-GUAM directly depends on the political will of elites, in particular, Ukrainian elites, that govern its member-states between elections. Thus, the ODED-GUAM is not an attractive, predictable, dependable core to support a defensive state framework.

If a "non-aligned" Intermarium-type organization is created, the nonalignment of member states will trigger a different type of security dilemma. The growing military might of the regional states will not only become a deterrent to Russia, but also pose a challenge to the TransAtlantic co-operation. Recent history reveals that regional states do not always follow mainstream NATO and EU policies. If they feel that they have accumulated a considerable military might, the level of discord will increase. The latter will lead to the restoration of the post-World War I scenario when the "non-aligned" regional states were squeezed between the sorehead Western and Eurasian superpowers.

If an Intermarium is created as a new NATO-bis framework on the premises of the Turkey-Azerbaijan agreement, this will-paradoxicallybring new opportunities to Russia. The latter will definitely find the weaknesses in interstate dependencies and use these weaknesses to provoke the Intermarium states by starting new conflicts or reviving old ones. Saryusz-Wolski believes that a NATO-bis framework would bring more chaos into the region. On the one hand, if Russian aggression triggers no military response from the allied states, this will "expose the Intermarium pact as a paper tiger. Moscow would triumph, proving that no political initiative in the region could flourish without explicit consent of Russia" (Saryusz-Wolski). On the other hand, if the allied states, specifically the NATO members, respond to Russian aggression with force, they will not be covered by the Article 5 guarantees: "As a result, one or more NATO members could end up in a military confrontation (even a limited one) with Russia without NATO support, eroding the deterrent effect of the alliance" (Saryusz-Wolski). The integrity of the Trans-Atlantic security system will be unnecessarily put at risk. As for the regional states, they will be further 
alienated from their NATO partners, and eventually will be left to face Russian aggression alone.

Therefore, the original concept of the Intermarium will not likely work in the contemporary geopolitical architecture. The number of challenges it would evoke significantly exceeds the number of benefits it would impart, especially for the "grey zone" states. Regional military and defence cooperation should be developed cautiously, flexibly, and within the frameworks of the Trans-Atlantic alliances. Military and defence cooperation should lead to the emergence of alignments rather than alliances, and this trend is taking place today.

\section{CONCLUSIONS}

If projected onto the contemporary geopolitical environment, the original Intermarium concept would comprise a set of unrealistic objectives shaped by historical and often over-inflated aspirations. Poland and Ukraine as the biggest states in the region between the Baltic and Black seas interpret these objectives differently, though both use the term "Intermarium." If the Intermarium emerged today in accordance to Pilsudski's vision, it would suffer from an economically inefficient and non-institutionalized framework. It would not be able to assure any significant achievements in military and defence co-operation. Moreover, it could be "hijacked" by rightwing populist movements to build agendas on its multilayeredness (Kott).

Poland and Ukraine, as the direct Intermarium "legatees," prefer to develop bilateral relations within European and Trans-Atlantic frameworks, which clearly contradicts the original conceptualizations by Piłsudski and other intellectuals at the beginning of the twentieth century. Nałęcz points out that if the Intermarium framework is ever to emerge, it will need at least three major prerequisites to fall into place: (1) the free will of the regional states to form a well-functioning international organization on a federate basis, or at least to form a defensive alliance; (2) a weakened Russian position that will either accept, or will not be able to prevent, the emergence of an Intermarium framework; (3) the non-engagement of the Western states, or at least their neutrality, in the Intermarium formation (Nałęcz, "The Evolution" 15-18). These three conditions have never coexisted in the twentieth century. Even while facing the threat of Nazi Germany in the late 1930s, Poland could not find reliable allies in the region; this serves as another illustration of the historical counterproductivity of the Intermarium concept (Dahl 63).

According to Mikhail Ilyin and Yelena Meleshkina, to form a viable geopolitical framework in the future, people of central and eastern European regions should be able to answer three questions. (1) What is the 
major existential idea behind the planned unity apart from being different from and threatened by larger neighbouring states stretched between Europe and Asia? (2) What is the added value this new grouping can bring to the world, apart from a long record of failures, errors, and wars? (3) What will be the role and place of the unified Intermarium community in global politics? (Ilyin and Meleshkina 72).

The term "Intermarium" evokes confusion and miscommunication because of the multilayeredness and ambiguous historical nature of such a community. The term is also a magnet for propaganda, and therefore, its use should be considered with that possibility in mind. Indisputably, regional co-operation between central and eastern European states should be further developed. The Three Seas Initiative, the Nordic-Baltic Eight, the Visegrád Group, and even the ODED-GUAM may provide successful examples of joined approaches to shared challenges. Saryusz-Wolski defines a successful example as one that produces "economic and political benefits for the whole continent" and holds "a potential to diminish the civilizational and economic divergence created by fifty years of communism." 
Works Cited

Archer, Clive, and Pertti Joenniemi. "Nordic Security and Defence Cooperation: Northern Policies in a European Perspective." Nordic Cooperation: A European Region in Transition, edited by Johan Strang, Routledge, 2015, pp 165-82.

Borkowski, Paweł J. "The Visegrád Group: Between the Legend of Fraternity and the Challenge of Peripherality." Place and Role of the Visegrád Group Countries in the European Union, edited by Józef M. Fiszer et al., Institute of Political Studies, the Polish Academy of Sciences \& Lazarski University, 2019, pp. 27-44.

Bugriy, Maksym. "Ukrainian-Polish Security Alignment. Pragmatism of Partnership." Intermarium: The Polish-Ukrainian Linchpin of the Baltic-Black Sea Cooperation, edited by Ostap Kushnir, Cambridge Scholars Publishing, 2019, pp. 113-41.

Bykanov, Denis. "Perspektivy Balto-Chernomorskogo sotrudnichestva." Kul'tura narodov Prichernomor'ia, vol. 15, 2000, pp. 56-63.

Chodakiewicz, Jan Marek. Intermarium: The Land between the Black and Baltic Seas. Transaction Publishers, 2012.

Chojan, Adrian. "The Visegrád Group and the Migration Crisis in Europe: A Discussion in the Context of the Global Strategy for the European Union's Foreign and Security Policy." Place and Role of the Visegrád Group Countries in the European Union, edited by Józef M. Fiszer et al., Institute of Political Studies, the Polish Academy of Sciences \& Lazarski University, 2019, pp. 87-102.

Dahl, Martin. “Inicjatywa Trójmorza z perspektywy niemieckiej.” Studia Europejskie, no. 2,2018 , pp. 59-72.

Domaradzki, Spasimir. "The Role of NATO and the EU in the Ukrainian Crisis." The Maidan Uprising, Separatism and Foreign Intervention: Ukraine's Complex Transition, edited by Klaus Bachmann and Igor Lyubashenko, Peter Lang GmbH, 2014, pp. 267-97.

Fedorenko, Kostiantyn, and Andreas Umland. "How to Solve Ukraine's Security Dilemma? The Idea of an Intermarium Coalition in East-Central Europe." War on the Rocks, 30 Aug. 2017, https://warontherocks.com/2017/08/how-tosolve-ukraines-security-dilemma-the-idea-of-an-intermarium-coalition-ineast-central-europe/. Accessed 23 Sept. 2019.

Fiszer, Józef M. "Integrative and Counter-Integrative Aspects of the EU Policies of the Visegrád Group Countries." Place and Role of the Visegrád Group Countries in the European Union, edited by Józef M. Fiszer et al., Institute of Political Studies, the Polish Academy of Sciences \& Lazarski University, 2019, pp. 45-68.

Forsberg, Tuomas, and Graeme Herd. "Russia and NATO: From Windows of Opportunities to Closed Doors." Journal of Contemporary European Studies, vol. 23, no. 1, 2015, pp. 41-57. DOI: 10.1080/14782804.2014.1001824

Gniazdowski, Mateusz. "Central European States Do Not Need Rivalry, They Need Joint Efforts." Interview by Octavian Milewski, Visegrad Insight, 29 June 2017, http://visegradinsight.eu/central-european-states-do-not-need-rivalry-theyneed-joint-efforts/. Accessed 13 Nov. 2018. 
Grzymski, Jan. "Seeing Like a European Border: Limits of the European Borders and Space." Global Discourse, vol. 9, no. 1, 2019, pp. 135-151. DOI: 10.1332/204378919X15470487645493

Honcharenko, Iurii. "Proekt Mizhmor''ia: vid kontseptsii do realizatsii." Foundation for Democracy Assistance, 20 November 2019, https://fpdi.org.ua/2017/06/09/iu-honcharenko-proekt-mizhmoria-vidkontseptsii-do-realizatsii/. Accessed 13 Feb. 2021.

Ilyin, Mikhail, and Yelena Meleshkina. "The Baltic-Pontic Region in the EuropeEurasia Dual System." Baltic Region, vol. 2, 2012, pp. 62-75. DOI: 10.5922/2079-8555-2012-2-7

Iso-Markku, Tuomas, et al. "A Stronger North? Nordic Cooperation in Foreign and Security Policy in a New Security Environment." Government's Analysis, Assessment, and Research Activities, vol. 37, May 2018, Finnish Institute of International Affairs, http://www.nordefco.org/files/nordic-vnteasreport_final.pdf. Accessed 5 June 2019.

Jabłoński, Miłosz. “Czy koncepcja 'Międzymorza' jest dzisiaj aktualna?” Centrum Analiz Kolibra, 2016, pp. 1-10. https://krakow.koliber.org/files/koncepcjami\%C4\%99dzymorza.pdf. Accessed 13 Nov. 2018.

Jaroszewicz, Marta, and Jan Grzymski. "Technocracy Revisited: The Polish Security Dispositif, Social Universes and Migration from Ukraine." Journal of Contemporary European Research, vol. 17, no. 2, 2021, pp. 258-80. DOI: 10.30950/jcer.v17i2.1215.

Klympush-Tsinsadze, Ivanna. "Ukraine Is Ready to Contribute into European and Euroatlantic Security." Ukraine Analitica, 14 Nov. 2016, http://ukraineanalytica.org/ukraine-is-ready-to-contribute-into-european-and-euroatlanticsecurity/. Accessed 13 Nov. 2018.

Kott, Matthew. "A Far Right Hijack of Intermarium.” New Eastern Europe, 26 May 2017, https://neweasterneurope.eu/2017/05/26/a-far-right-hijack-ofintermarium/. Accessed 13 Nov. 2018.

Kowal, Paweł, and Paweł Ukielski. "Ćwierć wieku polskiej polityki zagranicznej (1989-2014)." Horyzonty Polityki, vol. 5, no. 11, 2014, pp. 31-50.

Kushnir, Ostap. "Ukraine, Poland and the Intermarium: In the Midst of Ambiguity." Intermarium: The Polish-Ukrainian Linchpin of the Baltic-Black Sea Cooperation, edited by Ostap Kushnir, Cambridge Scholars Publishing, 2019, pp. 45-74.

---. "Ukrainian Policies in the Black Sea Littoral: History, Current Trends and Perspectives." Journal of Contemporary European Studies, vol. 25, no. 2, 2017, pp. 163-79. DOI: 10.1080/14782804.2016.1219845

---. Ukraine and Russian Neo-Imperialism: The Divergent Break. Lexington Books, 2018.

---, editor. Intermarium: The Polish-Ukrainian Linchpin of the Baltic-Black Sea Cooperation. Cambridge Scholars Publishing, 2019.

Masson, Francis. "The Three-Seas-Initiative: European Regionalism of Supranational Nature." Nouvelle Europe, 20 March 2018, http://www.nouvelleeurope.eu/en/three-seas-initiative-european-regionalism-supranationalnature. Accessed 13 Nov. 2018. 
Ministry of Foreign Affairs, Republic of Estonia. "Nordic-Baltic Cooperation (NB 8)." Ministry of Foreign Affairs, Republic of Estonia, 4 Feb. 2020, https://vm.ee/en/nordic-baltic-cooperation-nb-8. Accessed 5 June 2019.

Ministry of Foreign Affairs, Republic of Poland. "Exports of Arms and Military Equipment from Poland. 2015 Report." Gov.pl, http://www.msz.gov.pl/resource/19632e19-166a-43f9-bd61-

87532a1fcfce:JCR. Accessed 13 Nov. 2018.

Nałęcz, Daria. "Intermarium vs the Three Seas Initiative." New Eastern Europe, 6 July 2017, http://neweasterneurope.eu/2017/07/06/intermarium-vs-the-threeseas-initiative/. Accessed 22 Oct. 2018.

---. "The Evolution and Implementation of the Intermarium Strategy in Poland: A Historical Perspective." Intermarium: The Polish-Ukrainian Linchpin of the Baltic-Black Sea Cooperation, edited by Ostap Kushnir, Cambridge Scholars Publishing, 2019, pp. 1-21.

Napiórkowski, Tomasz. "Cooperation within the Intermarium and Economic Opportunities for Ukraine." Intermarium: The Polish-Ukrainian Linchpin of the Baltic-Black Sea Cooperation, edited by Ostap Kushnir, Cambridge Scholars Publishing, 2019, pp. 142-63.

Official Website of the President of the Republic of Poland. "Wspólna deklaracja w sprawie Inicjatywy Trójmorza." $\quad$ Prezydent.pl, https://www.prezydent.pl/aktualnosci/wizyty-zagraniczne/art,105,wspolnadeklaracja-w-sprawie-inicjatywy-trojmorza.html. Accessed 5 June 2019.

Osadczuk, Bohdan. “Ukraiński maj w polityce zagranicznej.” Kultura, vols. 7-8 (59899), 1997, pp. 138-49.

Poltorak, Volodymyr. "Ukraine and the Intermarium: From the Middle Ages to the Collapse of the USSR." Intermarium: The Polish-Ukrainian Linchpin of the BalticBlack Sea Cooperation, edited by Ostap Kushnir, Cambridge Scholars Publishing, 2019, pp. 22-44.

Pryshchepa, Kateryna. "Long Farewell to Giedroyc. Polish Discussion Regarding Relations with Ukraine." Intermarium: The Polish-Ukrainian Linchpin of the Baltic-Black Sea Cooperation, edited by Ostap Kushnir, Cambridge Scholars Publishing, 2019, pp. 75-112.

Putin, Vladimir. "Transcript: Putin Says Russia Will Protect the Rights of Russians Abroad." Washington Post, 18 March 2014, https://www.washingtonpost.com/world/transcript-putin-says-russia-willprotect-the-rights-of-russians-abroad/2014/03/18/432a1e60-ae99-11e3a49e-76adc9210f19 story.html. Accessed 16 Aug. 2015.

Ryabykh, Valery. "More Words, But Also Some Action in Ukraine-Poland Defence Cooperation." Defense Express, 2 May 2017, https://defenceua.com/index.php/en/publications/partners-publication/2829-more-wordsbut-also-some-action-in-ukraine-poland-defense-cooperation. Accessed 13 Nov. 2018.

Saryusz-Wolski, Jacek. "In between Security Arrangements: The Trojan Horse of Military Intermarium." War on the Rocks, 13 Oct. 2017, https://warontherocks.com/2017/10/in-between-security-arrangements-thetrojan-horse-of-military-intermarium/. Accessed 23 Sept. 2019. 
Shpak, Denys. "Balto-Chornomors'ke spivrobitnytstvo iak prohresyvnyi napriamok intehratsiinoi polityky Ukrainy." Naukovyi visnyk Dyplomatychnoi akademii Ukrainy, vol. 9, 2003, pp. 168-77.

Sosnowski, Adam. "Prezydent Andrzej Duda steruje ku Międzymorzu." Fronda.pl, 8 Sept. 2015, http://www.fronda.pl/a/prezydent-andrzej-duda-steruje-kumiedzymorzu,56586.html. Accessed 13 Nov. 2018.

State Statistics Service of Ukraine. "Dynamics of the Geographical Structure of Foreign Trade in Goods." Ukrstat.org, http://ukrstat.org/en/operativ/operativ2005/zd/zd_rik/zd_e/gs_rik_e.html. Accessed 13 Nov. 2018.

---. "Geographical Structure of Exports-Imports of Services by Countries in JanuarySeptember of 2017." Ukrstat.org, http://ukrstat.org/en/operativ/operativ2017/zd/gsztp/gsztp e/gsztp 9m201 7_e.html. Accessed 13 Nov. 2018.

"Szczerski: Inicjatywa Trójmorza to nowy pomysł na zwiększanie jedności europejskiej." Biznes Alert, 4 May 2017, https://biznesalert.pl/szczerskiinicjatywa-trojmorza-nowy-pomysl-zwiekszanie-jednosci-europejskiej/. Accessed 13 Feb. 2021.

Tsygankov, Andrei. “Vladimir Putin's Last Stand: The Sources of Russia's Ukraine Policy." Post-Soviet Affairs, vol. 31, no. 4, 2015, pp. 279-303. DOI: 10.1080/1060586X.2015.1005903

Umland, Andreas. "Intermarium: The Case for Security Pact of the Countries between the Baltic and Black Seas." IndraStra Global, vol. 2, no. 4, 2016, pp. 1-4. http://www.ssoar.info/ssoar/handle/document/48562. Accessed 13 Nov. 2018.

Vereshchuk, Iryna, and Andreas Umland. "How to Make Eastern Europe's Gray Zone Less Gray." Harvard International Review, vol. 40, no. 1, 2019, pp. 38-41. DOI: $10.2307 / 26617392$

Wishart, Alexandra. "How the Ukrainian Far-Right Has Become One of the Biggest Proponents of Intermarium." New Eastern Europe, 25 Sept. 2018, http://neweasterneurope.eu/2018/09/25/ukrainian-far-right-become-onebiggest-proponents-intermarium/. Accessed 13 Nov. 2018. 